\title{
Inhibitors of Hepatitis B Virus Attachment and Entry
}

\author{
Florian A. Lempp ${ }^{a}$ Stephan Urban ${ }^{a, b}$ \\ a Department of Infectious Diseases, Molecular Virology, University Hospital Heidelberg, and \\ ${ }^{b}$ German Center for Infection Research, Heidelberg University, Heidelberg, Germany
}

\section{Key Words}

Hepatitis B virus - Virus entry - Entry inhibition - Myrcludex

B - Sodium-taurocholate cotransporting polypeptide $\cdot$ NTCP could block reinfection and shield naive hepatocytes that emerge from natural liver turnover, opening up new therapeutic options.

(c) 2014 S. Karger AG, Basel

\begin{abstract}
Inhibition of virus entry has become a major concept in the development of new antiviral drugs. Entry inhibitors can either neutralize activities of viral surface proteins or target essential host factors such as (co)receptors. Due to its distinct tissue tropism and the highly specific viral and cellular factors involved in its entry, hepatitis B virus (HBV) is an ideal candidate for entry inhibition. Hepatitis $B$ immunoglobulins neutralize infection by binding to the S-domain of HBV surface proteins and are used to prevent reinfection of the graft after liver transplantation. Novel S or preS-specific monoclonal antibodies are currently in development. The identification of sodium-taurocholate cotransporting polypeptide (NTCP) as a bona fide receptor has revealed a suitable target for HBV entry inhibition. NTCP receptor function is blocked by a variety of different agents including Myrcludex B, a synthetic $\mathrm{N}$-acylated preS1-derived lipopeptide that inhibits HBV entry in vitro and in vivo with high efficacy. Current antiviral treatment for chronic HBV-infected patients focuses on the inhibition of the viral polymerase via nucleos(t)ide analogues (NA). Entry inhibitors in combination with NAs
\end{abstract}

\section{Introduction}

Inhibition of viral infections can be accomplished by targeting different steps of the viral life cycle. Most of the clinically used antiviral drugs interfere with replication in an already established infection. However, virus entry as a therapeutic target is receiving increasing attention with several drugs interfering with HIV, influenza, or respiratory syncytial virus entry [1]. Efficient entry inhibition can be achieved especially for viruses that show a distinct tropism for certain tissue-specific receptor proteins, as these factors can be antagonized selectively. In this regard, the highly hepatotropic hepatitis B virus (HBV) is an ideal candidate for entry inhibition. HBV is a small enveloped virus carrying a partially double-stranded DNA genome packaged in an icosahedrally shaped nucleocapsid. The capsid is surrounded by a lipid bilayer containing the surface glycoproteins L (large), M (middle), and S (small). All three proteins share the common C-terminal S-domain that is anchored in the lipid bilayer

\section{KARGER}

E-Mail karger@karger.com

www.karger.com/int
Prof. Dr. Stephan Urban

Department of Infectious Diseases, Molecular Virology, University Hospital Heidelberg Im Neuenheimer Feld 345

DE-69120 Heidelberg (Germany)

E-Mail stephan.urban@med.uni-heidelberg.de 
Table 1. Overview of HBV entry inhibitors including their latest clinical status

\begin{tabular}{|c|c|c|c|c|c|c|c|}
\hline Class & Substance & Molecule & Target & Clinical status & $\begin{array}{l}\text { IC50 HBV } \\
\text { inhibition }^{\ddagger}\end{array}$ & $\begin{array}{l}\text { Patients plasma } \\
\text { concentration }^{\dagger}\end{array}$ & Reference \\
\hline \multirow[t]{3}{*}{ Antibodies } & HBIG & Polyclonal Ab & $S$ & Approved & & & Samuel, 1993 [7] \\
\hline & KR127 & Monoclonal Ab & preS1 & Preclinical & & & Hong, 2004 [18] \\
\hline & 17.1.41/19.79.5 & Monoclonal Abs & $\mathrm{S}$ & Phase I & & & Galun, 2002 [15] \\
\hline $\begin{array}{l}\text { Attachment } \\
\text { inhibitors }\end{array}$ & SALP & Peptide & HSPG & Preclinical & $0.37 \mu \mathrm{M}$ & $\mathrm{n} / \mathrm{a}$ & Krepstakies, 2012 [26] \\
\hline \multirow{4}{*}{$\begin{array}{l}\text { NTCP } \\
\text { inhibitors }\end{array}$} & Myrcludex B & Peptide & NTCP & Phase II & $80 \mathrm{pM}$ & $\mathrm{n} / \mathrm{a}$ & Schulze, 2010 [33] \\
\hline & Cyclosporin A & Cyclic peptide & NTCP & Approved* & $1 \mu \mathrm{M}$ & $0.7 \mu \mathrm{M}$ & Nkongolo, 2013 [41] \\
\hline & SCYX1454139 & CsA-derivate & NTCP & Preclinical & $0.17 \mu \mathrm{M}$ & $\mathrm{n} / \mathrm{a}$ & Watashi, 2013 [43] \\
\hline & Ezetimibe & Small molecule & NTCP/NPC1L1 & Approved* & $18 \mu \mathrm{M}$ & $0.2 \mu \mathrm{M}$ & Lucifora, 2013 [46] \\
\hline
\end{tabular}

* Approved for indications other than HBV infection. ${ }^{*}$ As determined in vitro using HepaRG cells. ${ }^{\dagger}$ During therapy in the standard indication.

via four membrane-spanning helices. The $\mathrm{L}$ and $\mathrm{M}$ proteins have $\mathrm{N}$-terminal extensions (preS1/2 and preS2, respectively) that mediate diverse functions in nucleocapsid binding and receptor recognition [2].

Cell entry of HBV proceeds via at least two steps. Coming from the bloodstream into the space of Dissé, the virus initially interacts with heparan sulfate proteoglycans (HSPGs) on the hepatocyte surface. This attachment is mediated by the preS region of the L protein and the antigenic loop of the viral S protein $[3,4]$. Subsequently, the virus switches to its high-affinity receptor, the sodium-taurocholate cotransporting polypeptide (NTCP/ SLC10A1) [5, 6]. NTCP is an integral membrane protein that is exclusively expressed on the basolateral membrane of hepatocytes, which explains the tropism of $\mathrm{HBV}$ for the liver. In this review we discuss established and novel inhibitors of the HBV entry process, focusing on three different classes: antibodies that neutralize HBV via interaction with viral surface proteins, inhibitors of viral attachment, and molecules that antagonize NTCP receptor function (summarized in table 1).

\section{HBV-Neutralizing Antibodies}

Entry inhibition can interfere with HBV both during the acute and persistent phase of the infection: in the acute phase, shortly after the onset of an infection when the immune system only partly controls the pathogen, entry inhibitors can protect naive hepatocytes against uptake, replication, and dissemination of the virus. Long- term treatment during persistent infections may lead to viral clearance due to the natural or immune-mediated turnover of the infected hepatocytes in the liver. Interference with viral entry is currently in clinical use for the prevention of new infections, e.g. during post-exposure prophylaxis, perinatal transfer from an infected mother to her child, or after organ transplantation of HBV-infected patients suffering from liver failure.

The first and currently only clinically approved HBV entry inhibitor is hepatitis B immunoglobulin (HBIG), a mixture of $S$ protein-directed antibodies purified from the plasma of vaccinated individuals or, previously, from patients that have resolved the infection. HBIGs were first used in 1993 by Samuel et al. [7] who treated HBV-positive patients after liver transplantation. The administration for a prolonged period after transplantation decreased the rate of graft reinfection from 75 to $35 \%$ and significantly improved patient survival. The current clinical standard is the use of HBIGs in combination with nucleos(t)ide analogues (NA), which further decreases graft reinfection to less than 5\% [8]. HBIGs also have clinical benefit in the prevention of vertical transmission from mother to child when the newborns are treated with a combination of HBIGs and an HBV vaccine, and the mothers have been treated with NAs before delivery [9]. Treatment with HBIGs involves the risk of selecting virus variants with mutations in the antibody-binding sites that escape neutralization and establish infection in the liver graft or in newborns after vertical transmission [10].

Antibody-mediated neutralization of HBV is most effective when the antibodies are directed against one of the 
three infectivity determinant regions within the $\mathrm{L}$ and $\mathrm{S}$ proteins. Three of those regions are currently known: the antigenic loop of the S domain is a highly 3-dimensionalstructured region between the 2nd and 3rd transmembrane domains of S. Vaccine-induced antibodies as well as HBIGs recognize conformational epitopes within this region. The second determinant is located in the first transmembrane region and most likely has a role in membrane fusion [11]. However, antibodies directed against this transmembrane region have not been obtained in spite of intense efforts [W. Gerlich, pers. commun.]. The third and best characterized determinant is located within the $\mathrm{N}$-terminally myristoylated preS1 subdomain, spanning amino acids (AA) 2-75 [12]. Interestingly, antibodies targeting the very $\mathrm{N}$-terminal part of preS1 (AA 1-21) which also represents the essential receptor binding region [AA 9-NPLGF(F/L)P-15)] are nonneutralizing as this region seems to be shielded by $\mathrm{N}$-terminal myristoylation [13] (fig. 1).

Besides HBIGs, several monoclonal antibodies (mAbs) targeting $S$ or preS have been developed, but none of them have reached approval for therapeutic use so far. Two fully humanized S-specific mAbs (17.1.41 and 19.79.5) reduced HBsAg levels in chronically infected chimpanzees [14]. In a phase I clinical trial, a combination of both antibodies reduced HBV viral titer and suppressed $\mathrm{HBsAg}$ to undetectable levels. However, this suppression lasted only for several days after administration [15]. Unfortunately, these trials were not continued. The preS1-specific $\mathrm{mAb}$ Ma18/7 was raised against purified HBV particles and allowed identification of the L protein [16]. Later, it showed potent HBV neutralization in vitro [17], but was never further developed towards clinical trials. The $\mathrm{mAb}$ KR127, which binds three AAs downstream of the Ma18/7 epitope, inhibited HBV infection in chimpanzees [18]. Novel, highly specific mAbs would have a broad area of applications, such as prevention of infection during postexposure prophylaxis or after liver transplantation.

\section{Inhibitors of HSPG-Mediated Attachment}

Entry of HBV initiates with binding of the virion to HSPGs on the surface of the hepatocyte [3, 19] (fig. 2). It has been shown that highly sulfated polysaccharides interfere with HBV infection and that pretreatment of the cells with heparinase or sodium chlorate (to prevent sulfation of glycoproteins) severely impairs infection. Attachment of HBV to HSPGs requires both the preS region of the $\mathrm{L}$ protein and the antigenic loop region

Inhibitors of HBV Attachment and Entry (involving Arg- or Lys-122 and Lys-141) in the S protein $[3,4]$.

Heparin, a soluble highly sulfated glycosaminoglycan, inhibits $\mathrm{HBV}$ infection in vitro at an $\mathrm{IC}_{50}$ of $9.4 \mu \mathrm{g} / \mathrm{ml}$ [3]. Heparin is clinically used as an anticoagulant which binds to antithrombin III, consequently inhibiting the blood clotting cascade. It is assumed that heparin binds to the HBV surface proteins, thereby shielding the virus from interaction with cellular HSPGs. The same mechanism of action is proposed for suramin, a highly sulfated naphthylamine derivative of urea, which was previously shown to interfere with early steps of duck HBV infection in vitro and in vivo [20,21]. Entry inhibition of HBV was verified at an $\mathrm{IC}_{50}$ of $33 \mu \mathrm{g} / \mathrm{ml}$ using the HepaRG system [3]. Suramin has therapeutic activity against a variety of different targets. It has been used since the $1920 \mathrm{~s}$ for the prophylactic treatment of human trypanosomiasis. Due to its inhibitory activity on viral reverse transcriptases, it was tested in a clinical trial against HIV infections, but failed to show an effect [22]. Since the 1980s it was and is still being used in trials with different indications of cancer $[23,24]$. In 1987, a clinical study involving $3 \mathrm{HBV}$-infected patients treated with suramin was aborted due to toxicity and ineffectiveness of the treatment [25].

HSPGs are host factors that are used by a variety of different viruses for primary attachment and in some cases entry. Therefore, they represent an ideal target for specific antiviral therapy aiming at the inhibition of multiple virus infections and coinfections. Beside soluble factors that bind HSPGs like poly-L-lysine, synthetic antilipopolysaccharide peptides have been described as binding partners for HSPGs. The presence of synthetic antilipopolysaccharide peptides during in vitro infection inhibited entry of a variety of enveloped viruses including herpes simplex virus, hepatitis $\mathrm{C}$ virus, HIV, and HBV [26].

\section{NTCP-Directed Inhibitors}

NTCP, a bile salt transporter that is exclusively expressed on the basolateral membrane of hepatocytes, was recently identified in a biochemical approach as the longsought receptor for HBV [6]. NTCP is not only crucial for the liver tropism of HBV, but also determines species specificity, as NTCP from the cynomolgus monkey is neither able to bind HBV nor does it confer susceptibility towards $\mathrm{HBV}$ infection due to a sequence alteration at AA positions 157-165. Mouse hepatocytes [27] and consis- 
Fig. 1. Domain structure and neutralizing epitopes of the three HBV surface proteins. The three envelope proteins $\mathrm{L}, \mathrm{M}$, and $\mathrm{S}$ share the common S domain, which is anchored in the membrane via four putative transmembrane domains. The $\mathrm{M}$ protein has an N-terminal extension of 55 AA (preS2), and the N-terminally myristoylated L protein has a further extension spanning 108 AA (preS1). Antibody epitopes and their locations are illustrated by black bars with red antibodies representing regions that have neutralization potential and blue antibodies describing epitopes that fail to neutralize infection. The entry inhibitor Myrcludex B is derived from the first 48 AA of preS1 containing the essential receptor binding motif 9-NPLGF(F/L) $\mathrm{P}-15$. AGL $=$ Antigenic loop.

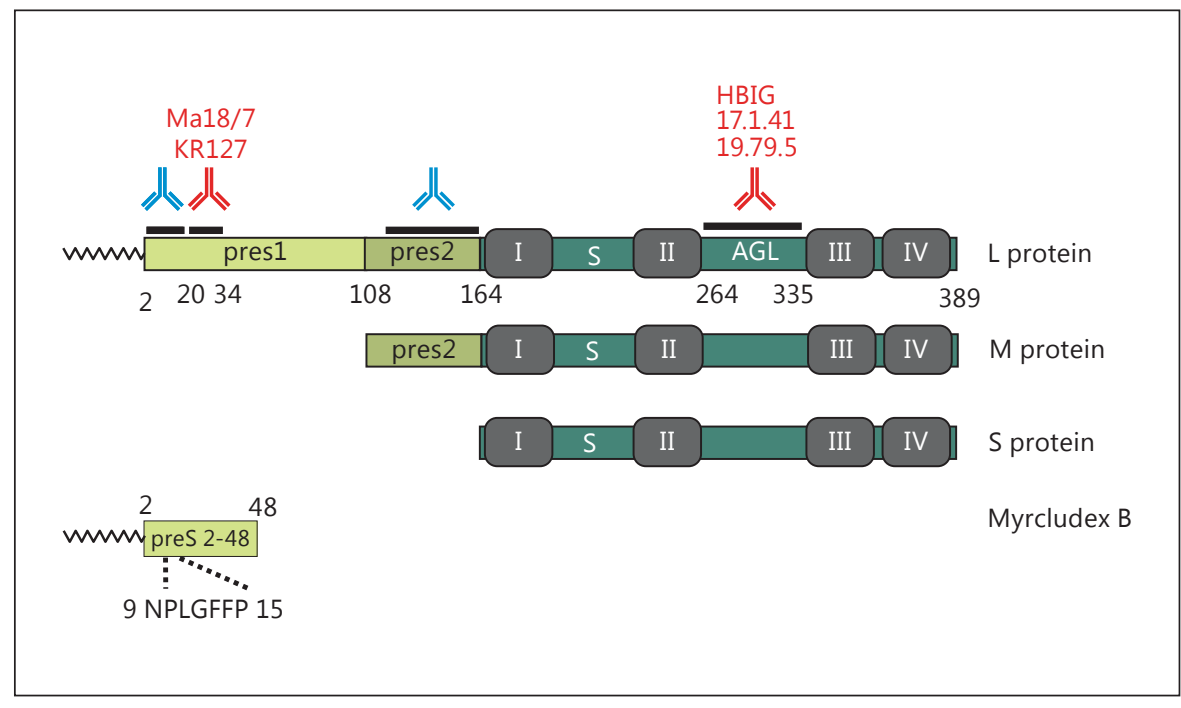

Fig. 2. Model of the HBV entry pathway including antiviral targets and inhibitors. Entry of $\mathrm{HBV}$ requires attachment to HSPGs before transition to the high-affinity receptor NTCP. NTCP is exclusively sorted to the basolateral membrane and probably participates in the endocytosis of the virus. HBIGs and other antibodies neutralize infection by binding to the HBV surface proteins. Heparin and suramin bind to the $\mathrm{HBV}$ surface proteins, thereby shielding the virion from interactions with HSPGs. Synthetic antilipopolysaccharide peptides (SALP) directly bind to and block HSPGs. Cyclosporine $\mathrm{A}$ and ezetimibe inhibit NTCP transport function and interfere with infection. The preS1-derived lipopeptide Myrcludex B specifically binds to NTCP, thereby blocking infection. It is currently unclear if Myrcludex B interferes with NTCP binding or in a later step during fusion.

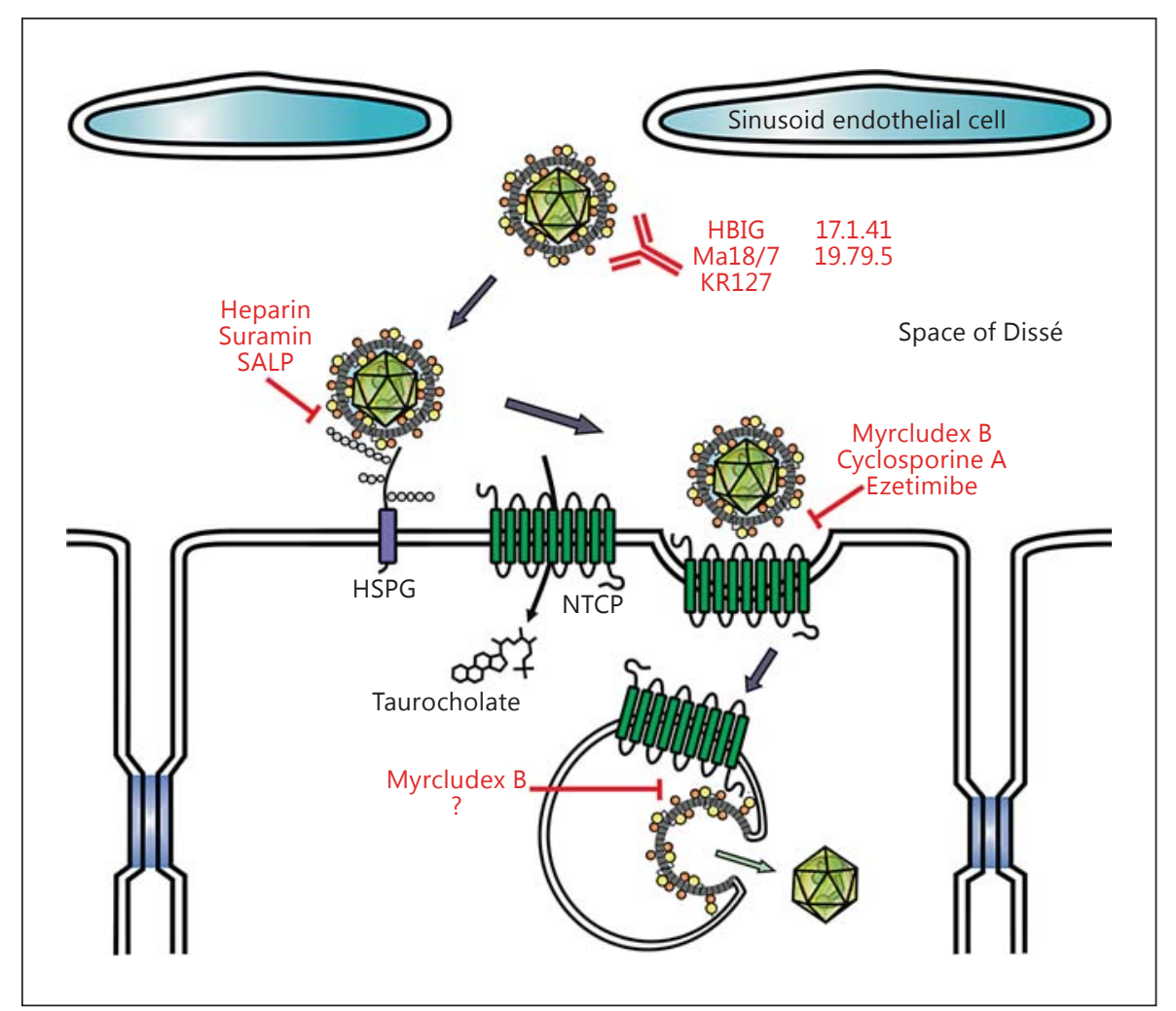

tently mouse NTCP are able to bind the HBV L surface protein; however, mouse NTCP does not confer susceptibility to HBV due to a sequence alteration at AA positions $84-87[5,6,28]$. Surprisingly, primary hepatocytes of the distantly primate-related small mammal Tupaia belangeri are suitable in vitro models for the HBV infec- tion $[29,30]$. The NTCP of tupaias is very similar to the human NTCP and also confers susceptibility to HBV [6].

Liver-specific expression and specific interaction with the virus favors NTCP as an ideal target for HBV entry inhibition. HBV binds to NTCP via the preS1-domain of the viral L protein. The ability of the myristoylated preS1 
domain to address an HBV-specific receptor was first observed with a myristoylated peptide comprising AA 2-78 of preS1 that specifically inhibited HBV infection in HepaRG cells and primary human hepatocytes [31]. As the inhibitory effect of such a peptide had already been observed when given prior to (or during) infection, a direct interaction with the receptor was hypothesized. Mapping studies revealed a strong dependence on the $\mathrm{N}$-terminal fatty acid moiety as well as of the AA sequence 9-NPLGF(F/L)P-15 [29, 32, 33]. This sequence stretch is conserved in all human and primate hepadnaviruses and even in the recently identified bat HBV [34], indicating that they all target homologous receptors. Later on, it was shown that shortening of the lipopeptide to AA 2-48 increased the activity [35]. Furthermore, definition of a lead substance (Myrcludex B) adapted to a consensus sequence resulted in the most powerful inhibition with an $\mathrm{IC}_{50}$ of approximately $80 \mathrm{pM}$ [33].

Interference with $\mathrm{HBV}$ entry was further validated in an in vivo mouse model. Liver-chimeric uPA-SCID mice were treated via different administration routes with Myrcludex B and related lipopeptides prior to HBV infection. Even very low subcutaneous doses $(0.2 \mathrm{mg} / \mathrm{kg})$ of the peptide completely abrogated the establishment of an $\mathrm{HBV}$ infection [36]. Moreover, when administered 3 days or 3 weeks after the establishment of an infection, Myrcludex $B$ inhibited virus spread in the liver, indicating that intrahepatic HBV spread depends on de novo infections mediated by NTCP [37].

Myrcludex B is highly selective in targeting hepatocytes. As seen in pharmacokinetic studies, the peptide rapidly accumulates in the liver even of non-HBV-susceptible animals like mice, dogs, and rats, but not in cynomolgus monkeys as discussed above [38]. Binding of Myrcludex B to NTCP not only inhibits HBV infection at low concentrations, but also blocks the uptake of bile salts, the physiological function of NTCP when given at saturating concentrations $[5,39]$. The possible clinical consequences of such an inhibition during treatment with Myrcludex B are not yet clear. However, increased bile salt levels in the serum might be compensated by an induced expression of other liver-specific bile salt transporters like the members of the OATP family.

Individuals carrying a homozygous SNP (C800T) in NTCP, which severely impairs bile salt transport, have been described, indicating that compensation by other transporters may be possible [40]. Interestingly, Myrcludex B-dependent infection inhibition occurs at an almost 1,000 -fold lower $\mathrm{IC}_{50}$ than bile salt uptake inhibition (83
pM vs. $52 \mathrm{nM}$ ) [41], indicating a dominant negative inhibitory effect of Myrcludex B on HBV infection. This opens up a large therapeutic dosage window, in which HBV infection can be efficiently inhibited without severe impairment of bile salt transportation. Myrcludex B passed acute and long-term toxicity studies and is currently in phase II clinical trials in chronically $\mathrm{HBV}-/$ HDV-infected patients.

Recent evidence suggests that the molecular determinants of NTCP critical for bile salt transportation overlap with those needed for infection, as infection can be inhibited by unphysiologically high concentrations of bile salts as well as by mutations in sodium or substrate-binding residues of NTCP that impair bile salt transportation $[5,39]$. It is still under debate whether the bile salt transportation function of NTCP is really needed for HBV infection, as infection is possible in sodium-depleted medium where no transport function can be observed [39]. Nevertheless, inhibitors of NTCP-dependent bile salt transportation are possible candidates for entry inhibition. Dong et al. [42] characterized 72 FDA-approved drugs on their ability to inhibit NTCP-dependent bile salt uptake. One of the compounds they describe is the immunosuppressive drug cyclosporine A, a well-known inhibitor of NTCP. Two recent publications have shown that cyclosporine A interferes with HBV entry in a cyclophilin-independent manner by direct interaction with NTCP. Infection inhibition was shown at an $\mathrm{IC}_{50}$ of approximately $1 \mu \mathrm{M}$ in HepaRG, primary human hepatocyte, and HepG2-hNTCP cells $[41,43]$. Cyclosporine A derivatives such as SCYX1454139 inhibit at even lower IC $_{50}$ values $(0.17 \mu \mathrm{M})$ [43]. A further drug that inhibits bile salt uptake by NTCP is ezetimibe, which is clinically used for the treatment of hypercholesterolemia and which was recently discovered to inhibit hepatitis $C$ virus infection by interaction with the host factor NiemannPick C1-like 1 (NPC1L1) [44, 45]. Lucifora et al. [46] reported that ezetimibe is able to block HBV infection during an early step of the lifecycle. This inhibition was independent from NPC1L1 as its knockdown did not abrogate the antiviral effect, suggesting that direct interaction between ezetimibe and NTCP may be the cause for infection inhibition.

\section{Conclusions}

Current treatments for chronic hepatitis B suppress viral replication, but rarely result in HBsAg seroconversion or viral clearance. Entry inhibitors present promis- 
ing novel therapeutic tools as a part of future strategies aiming at curative treatments. They could complement the current NA-based treatment in a way that not only intracellular replication of $\mathrm{HBV}$ but also reinfection of naive hepatocytes can be blocked. Natural viral clearance is mostly achieved by T cell-mediated killing of infected hepatocytes. During acute infection, entry inhibitors like Myrcludex B are able to inhibit viral spread and therefore reduce the number of infected hepatocytes that need to be cleared by the immune system. This treatment approach can be used after liver transplantation or to prevent vertical transmission from mother to child. NAs potently suppress virus replication in chronically infected patients; however, infection of naive he- patocytes still occurs. Entry inhibitors in combination with NAs could block reinfection and shield naive hepatocytes that emerge from natural liver turnover, leading to a faster elimination of infected cells. Future drugs might reactivate the immune system in chronically infected patients, thereby enhancing the hepatocyte turnover. Over the last years, knowledge about HBV entry has drastically increased. The identification of NTCP as a bona fide receptor has unveiled a powerful target for highly specific interference with early infection events. The development of inhibitors for viral and cellular attachment factors will soon generate novel drugs with major clinical significance.

\section{References}

$>1$ Teissier E, Penin F, Pecheur EI: Targeting cell entry of enveloped viruses as an antiviral strategy. Molecules 2011;16:221-250.

-2 Baumert TF, Meredith L, Ni Y, Felmlee DJ, McKeating JA, Urban S: Entry of hepatitis B and $C$ viruses - recent progress and future impact. Curr Opin Virol 2014;4C:58-65.

$>3$ Schulze A, Gripon P, Urban S: Hepatitis B virus infection initiates with a large surface protein-dependent binding to heparan sulfate proteoglycans. Hepatology 2007;46:17591768.

4 Sureau C, Salisse J: A conformational heparan sulfate binding site essential to infectivity overlaps with the conserved hepatitis $B$ virus a-determinant. Hepatology 2013;57:985-994.

$>5 \mathrm{Ni} \mathrm{Y,} \mathrm{Lempp} \mathrm{FA,} \mathrm{Mehrle} \mathrm{S,} \mathrm{Nkongolo} \mathrm{S,}$ Kaufman C, Falth M, Stindt J, Koniger C, Nassal M, Kubitz R, Sultmann H, Urban S: Hepatitis B and D viruses exploit sodium taurocholate co-transporting polypeptide for species-specific entry into hepatocytes. Gastroenterology 2014;146:1070-1083.

-6 Yan H, Zhong G, Xu G, He W, Jing Z, Gao Z, Huang Y, Qi Y, Peng B, Wang H, Fu L, Song M, Chen P, Gao W, Ren B, Sun Y, Cai T, Feng $\mathrm{X}$, Sui J, Li W: Sodium taurocholate cotransporting polypeptide is a functional receptor for human hepatitis B and D virus. Elife 2012; 1:e00049.

$>7$ Samuel D, Muller R, Alexander G, Fassati L, Ducot B, Benhamou JP, Bismuth H: Liver transplantation in European patients with the hepatitis B surface antigen. N Engl J Med 1993;329:1842-1847.

$>8$ Cholongitas E, Papatheodoridis GV: Review of the pharmacological management of hepatitis B viral infection before and after liver transplantation. World J Gastroenterol 2013; 19:9189-9197.
>9 Han GR, Cao MK, Zhao W, Jiang HX, Wang CM, Bai SF, Yue X, Wang GJ, Tang X, Fang ZX: A prospective and open-label study for the efficacy and safety of telbivudine in pregnancy for the prevention of perinatal transmission of hepatitis B virus infection. J Hepatol 2011;55:1215-1221.

10 Protzer-Knolle U, Naumann U, Bartenschlager R, Berg T, Hopf U, Meyer zum Buschenfelde KH, Neuhaus P, Gerken G: Hepatitis B virus with antigenically altered hepatitis B surface antigen is selected by highdose hepatitis B immune globulin after liver transplantation. Hepatology 1998;27:254263.

11 Berting A, Fischer C, Schaefer S, Garten W, Klenk HD, Gerlich WH: Hemifusion activity of a chimeric influenza virus hemagglutinin with a putative fusion peptide from hepatitis B virus. Virus Res 2000;68:35-49.

12 Blanchet M, Sureau C: Infectivity determinants of the hepatitis $\mathrm{B}$ virus pre-S domain are confined to the $\mathrm{N}$-terminal 75 amino acid residues. J Virol 2007;81:5841-5849.

13 Bremer CM, Sominskaya I, Skrastina D, Pumpens P, El Wahed AA, Beutling U, Frank R, Fritz HJ, Hunsmann G, Gerlich WH, Glebe D: N-terminal myristoylation-dependent masking of neutralizing epitopes in the preS1 attachment site of hepatitis B virus. J Hepatol 2011;55:29-37.

14 Eren R, Ilan E, Nussbaum O, Lubin I, Terkieltaub D, Arazi Y, Ben-Moshe O, Kitchinzky A, Berr S, Gopher J, Zauberman A, Galun E, Shouval D, Daudi N, Eid A, Jurim O, Magnius LO, Hammas B, Reisner Y, et al: Preclinical evaluation of two human anti-hepatitis B virus (HBV) monoclonal antibodies in the $\mathrm{HBV}$-trimera mouse model and in HBV chronic carrier chimpanzees. Hepatology 2000;32:588-596.
15 Galun E, Eren R, Safadi R, Ashour Y, Terrault N, Keeffe EB, Matot E, Mizrachi S, Terkieltaub D, Zohar M, Lubin I, Gopher J, Shouval D, Dagan S: Clinical evaluation (phase I) of a combination of two human monoclonal antibodies to HBV: safety and antiviral properties. Hepatology 2002;35:673-679.

$>16$ Heermann KH, Goldmann U, Schwartz W, Seyffarth T, Baumgarten H, Gerlich WH: Large surface proteins of hepatitis B virus containing the pre-s sequence. J Virol 1984; 52:396-402.

17 Glebe D, Aliakbari M, Krass P, Knoop EV, Valerius KP, Gerlich WH: Pre-s1 antigen-dependent infection of Tupaia hepatocyte cultures with human hepatitis B virus. J Virol 2003;77:9511-9521.

18 Hong HJ, Ryu CJ, Hur H, Kim S, Oh HK, Oh MS, Park SY: In vivo neutralization of hepatitis B virus infection by an anti-preS1 humanized antibody in chimpanzees. Virology 2004; 318:134-141.

19 Leistner CM, Gruen-Bernhard S, Glebe D: Role of glycosaminoglycans for binding and infection of hepatitis B virus. Cell Microbiol 2008;10:122-133.

20 Offensperger WB, Offensperger S, Walter E, Blum HE, Gerok W: Suramin prevents duck hepatitis B virus infection in vivo. Antimicrob Agents Chemother 1993;37:1539-1542.

$\checkmark 21$ Petcu DJ, Aldrich CE, Coates L, Taylor JM, Mason WS: Suramin inhibits in vitro infection by duck hepatitis B virus, Rous sarcoma virus, and hepatitis delta virus. Virology;167: 385-392.

22 Kaplan LD, Wolfe PR, Volberding PA, Feorino P, Levy JA, Abrams DI, Kiprov D, Wong R, Kaufman L, Gottlieb MS: Lack of response to suramin in patients with AIDS and AIDSrelated complex. Am J Med 1987;82:615-620. 
$\checkmark 23$ Lustberg MB, Pant S, Ruppert AS, Shen T, Wei Y, Chen L, Brenner L, Shiels D, Jensen RR, Berger M, Mrozek E, Ramaswamy B, Grever M, Au JL, Wientjes MG, Shapiro CL: Phase I/II trial of non-cytotoxic suramin in combination with weekly paclitaxel in metastatic breast cancer treated with prior taxanes. Cancer Chemother Pharmacol 2012;70:4956.

-24 Stein CA, LaRocca RV, Thomas R, McAtee N, Myers CE: Suramin: an anticancer drug with a unique mechanism of action. J Clin Oncol 1989;7:499-508.

-25 Loke RH, Anderson MG, Coleman JC, Tsiquaye KN, Zuckerman AJ, Murray-Lyon IM: Suramin treatment for chronic active hepatitis B - toxic and ineffective. J Med Virol 1987; 21:97-99.

-26 Krepstakies M, Lucifora J, Nagel CH, Zeisel MB, Holstermann B, Hohenberg H, Kowalski I, Gutsmann T, Baumert TF, Brandenburg K, Hauber J, Protzer U: A new class of synthetic peptide inhibitors blocks attachment and entry of human pathogenic viruses. J Infect Dis 2012;205:1654-1664.

-27 Meier A, Mehrle S, Weiss TS, Mier W, Urban S: Myristoylated PreS1-domain of the hepatitis B virus L-protein mediates specific binding to differentiated hepatocytes. Hepatology 2013;58:31-42.

-28 Yan H, Peng B, He W, Zhong G, Qi Y, Ren B, Gao Z, Jing Z, Song M, Xu G, Sui J, Li W: Molecular determinants of hepatitis $B$ and $D$ virus entry restriction in mouse sodium taurocholate cotransporting polypeptide. J Virol 2013;87:7977-7991.

-29 Glebe D, Urban S, Knoop EV, Cag N, Krass P, Grun S, Bulavaite A, Sasnauskas K, Gerlich WH: Mapping of the hepatitis B virus attachment site by use of infection-inhibiting preS1 lipopeptides and tupaia hepatocytes. Gastroenterology 2005; 129:234-245.

30 Köck J, Nassal M, MacNelly S, Baumert TF, Blum HE, von Weizsäcker F: Efficient infection of primary tupaia hepatocytes with purified human and woolly monkey hepatitis $\mathrm{B}$ virus. J Virol 2001;75:5084-5089.
1 Gripon P, Rumin S, Urban S, Le Seyec J, Glaise D, Cannie I, Guyomard C, Lucas J, Trepo C, Guguen-Guillouzo C: Infection of a human hepatoma cell line by hepatitis B virus. Proc Natl Acad Sci USA 2002;99:15655-15660.

32 Engelke M, Mills K, Seitz S, Simon P, Gripon P, Schnolzer M, Urban S: Characterization of a hepatitis $\mathrm{B}$ and hepatitis delta virus receptor binding site. Hepatology 2006;43:750-760.

33 Schulze A, Schieck A, Ni Y, Mier W, Urban S: Fine mapping of pre-S sequence requirements for hepatitis B virus large envelope protein-mediated receptor interaction. J Virol 2010;84:1989-2000.

34 Drexler JF, Geipel A, König A, et al: Bats carry pathogenic hepadnaviruses antigenically related to hepatitis B virus and capable of infecting human hepatocytes. Proc Natl Acad Sci USA 2013;110:16151-16156.

35 Gripon P, Cannie I, Urban S: Efficient inhibition of hepatitis B virus infection by acylated peptides derived from the large viral surface protein. J Virol 2005;79:1613-1622.

-36 Petersen J, Dandri M, Mier W, Lutgehetmann M, Volz T, von WF, Haberkorn U, Fischer L, Pollok JM, Erbes B, Seitz S, Urban S: Prevention of hepatitis $B$ virus infection in vivo by entry inhibitors derived from the large envelope protein. Nat Biotechnol 2008;26:335341.

Volz T, Allweiss L, Ben MBarek M, Warlich M, Lohse AW, Pollok JM, Alexandrov A, Urban S, Petersen J, Lutgehetmann M, Dandri M: The entry inhibitor Myrcludex-B efficiently blocks intrahepatic virus spreading in humanized mice previously infected with hepatitis B virus. J Hepatol 2013;58:861867.

38 Schieck A, Schulze A, Gähler C, Müller T, Haberkorn U, Alexandrov A, Urban S, Mier $\mathrm{W}$ : Hepatitis B virus hepatotropism is mediated by specific receptor recognition in the liver and not restricted to susceptible hosts. Hepatology 2013;58:43-53.
9 Yan H, Peng B, Liu Y, Xu G, He W, Ren B, Jing Z, Sui J, Li W: Viral entry of Hepatitis B and $\mathrm{D}$ viruses and bile salts transportation share common molecular determinants on sodium taurocholate cotransporting polypeptide. J Virol 2014;88:3273-3284.

40 Pan W, Song IS, Shin HJ, Kim MH, Choi YL, Lim SJ, Kim WY, Lee SS, Shin JG: Genetic polymorphisms in $\mathrm{Na}$-taurocholate cotransporting polypeptide (NTCP) and ileal apical sodium-dependent bile acid transporter (ASBT) and ethnic comparisons of functional variants of NTCP among Asian populations. Xenobiotica 2011;41:501-510.

41 Nkongolo S, Ni Y, Lempp FA, Kaufman C, Lindner T, Esser-Nobis K, Lohmann V, Mier W, Mehrle S, Urban S: Cyclosporin A inhibits hepatitis $B$ and hepatitis D virus entry by cyclophilin-independent interference with the NTCP receptor. J Hepatol 2014;60:723-731.

42 Dong Z, Ekins S, Polli JE: Structure-activity relationship for FDA approved drugs as inhibitors of the human sodium taurocholate cotransporting polypeptide (NTCP). Mol Pharm 2013;10:1008-1019.

43 Watashi K, Sluder A, Daito T, Matsunaga S, Ryo A, Nagamori S, Iwamoto M, Nakajima S, Tsukuda S, Borroto-Esoda K, Sugiyama M, Tanaka Y, Kanai Y, Kusuhara H, Mizokami M, Wakita T: Cyclosporin A and its analogs inhibit hepatitis B virus entry into cultured hepatocytes through targeting a membrane transporter NTCP. Hepatology 2013, Epub ahead of print.

44 Phan BA, Dayspring TD, Toth PP: Ezetimibe therapy: mechanism of action and clinical update. Vasc Health Risk Manag 2012;8:415427.

45 Sainz B, Jr, Barretto N, Martin DN, Hiraga N, Imamura $\mathrm{M}$, Hussain S, Marsh KA, Yu X, Chayama K, Alrefai WA, Uprichard SL: Identification of the Niemann-Pick C1-like 1 cholesterol absorption receptor as a new hepatitis C virus entry factor. Nat Med 2012;18:281285.

-46 Lucifora J, Esser K, Protzer U: Ezetimibe blocks hepatitis $\mathrm{B}$ virus infection after virus uptake into hepatocytes. Antiviral Res 2013; 97:195-197. 